\title{
A Discursive Approach in Analyzing Preservice Teachers' Discourse of Becoming a Science Teacher
}

\author{
Pei-Ling $\mathrm{Hsu}^{1}$ \\ ${ }^{1}$ Department of Teacher Education, College of Education, University of Texas at El Paso, El Paso, USA \\ Correspondence: Pei-Ling Hsu, Department of Teacher Education, College of Education, University of Texas at El \\ Paso, 500 W. University Avenue, El Paso, 79968, TX, USA.
}

Received: May 13, 2016

doi:10.5430/irhe.v1n2p89
Accepted: June 5, 2016

Online Published: June 17, 2016

URL: http://dx.doi.org/10.5430/irhe.v1n2p89

\begin{abstract}
One objective of many science educators is to recruit more science teachers. Researchers have investigated factors and influences that guide students to choose science teaching as a career. However, few investigations have studied the forms of language available for articulating becoming/being a science teacher. The purpose of this study is to investigate ways of using language to support justifications of becoming a science teacher. Drawing on discursive psychology, the study examines the repertoires preservice teachers use to articulate their future careers as science teachers. The results indicate that preservice teachers mainly draw on formative, performative, and consequential repertoires to articulate their career aspirations, while the potential repertoire is the least used. Implications of this study are discussed.
\end{abstract}

Keywords: preservice teachers, interpretative repertoires, discourse analysis

\section{Introduction}

The career development of science teachers is an important topic in science education because of the shortage and attrition of science teachers in the United States. Research shows that $58 \%$ of $\mathrm{K}-12$ schools reported difficulty in filling teaching job openings and $46 \%$ of beginning teachers left their jobs after five years (Ingersoll, 2003; Olsen, \& Anderson, 2007). In comparison with other fields, science and mathematics teachers left teaching at higher rates (Borman \& Dowling, 2008; Guarino, Santibanez, \& Daley, 2006). Specifically, after the first year of teaching, more than $18 \%$ of science teachers left, $14.5 \%$ of mathematics teachers left, and $12.3 \%$ of other teachers left (Ingersoll, Merrill, \& May 2012). This high attrition rate causes significant challenges and burdens for schools and for students financially and academically (Grissmer, Flanagan, Kawata, \& Williamson, 2000). The cost of replacing teachers within United States public schools can reach \$2.2 billion per year (Borman \& Dowling, 2008).

To address the shortage of science teachers, the National Academy of Science (2007) highlights the urgency to recruit more science and mathematics teachers in the United States, optimally 10,000 each year to improve science and science education in the United States. Understanding students' rationale of becoming science teachers is therefore important because it allows us to see from students' perspectives what made them consider becoming science teachers. Research shows that preservice teachers in the United States are predominantly white females (National Research Council, 2010) who enter the teaching profession for altruistic reasons to serve society (Guarino et al., 2006). They usually have experience working with children and report a favorite science teacher who influenced them to consider becoming a science teacher themselves (Weiss, 2007). Richardson and Watt (2006) identified the following factors that influence preservice teachers' decisions in choosing the profession of teaching: teaching abilities, intrinsic career value, fallback career, job security, time for family, job transferability, shaping the future of children/adolescents, enhancing social equity, making a social contribution, working with children/adolescents, prior teaching and learning experiences, and social influences.

These studies help us to understand possible factors that might mediate individuals' decision making for choosing teaching as a career. Little research, however, has studied the ways preservice teachers articulate their career choices. In this study, I take a different approach from that which is usually taken to career aspirations. Rather than assuming that individual characteristics fully explain career trajectories, I utilize a discursive psychological approach that presupposes that the science learning and teaching discourse students utilize is culturally learned and therefore constitutes a widely shared collective phenomenon. It is because the discourse is shared that interviewer and 
interviewees can understand each other while talking about career and life choices. Thus, the purpose of the study is to identify interpretative repertoires preservice teachers draw on when asked about their choice to become a science teacher. Meanwhile, the study also investigates how these interpretative repertoires interact with preservice teachers' identities in becoming a science teacher.

\section{Theoretical Framework: Discursive Psychology}

Initiated by Edwards and Potter (1992), discursive psychology is a relatively new perspective in the area of language and social psychology with great potential for science education research (Roth, 2008). It was influenced by, and constitutes a further elaboration of, Wittgenstein's (1958) later philosophy on language, ethnomethodology (e.g., Garfinkel, 1967), rhetoric (e.g., Billig, 1985), sociology of science (e.g., Gilbert \& Mulkay, 1984), conversation analysis (e.g., Atkinson \& Heritage, 1984), and discourse analysis (e.g., Potter \& Wetherell, 1987). In the past, psychologists have typically seen language as a resource and a medium, providing clues as to what is going on inside people's minds. Discursive psychology, however, theorizes language both as a means for conducting interactions and as a topic within these interactions; discursive psychology uses rigorous analytical procedures to examine how people construct everyday life (Edwards \& Potter, 1992). Interpretative repertoires denote forms of talking which discourse participants unquestioningly take for granted for the purpose at hand but also draw on to buttress other aspects of talk that are contentious and uncertain. Repertoires are generalized cultural patterns, ways of talking; people do not have to defend them, but speakers use them in - and listeners accept them as - support of claims. To be able to function this way, these repertoires have to be recognizable to their audience. That is, these repertoires are intelligible and exist in the culture of the discourse that is shared by the speaker and the listener. For career discourses, four repertoires are identified to articulate ways of pursuing a certain career (Hsu, Roth, Marshall, \& Guenette, 2009): formative, performative, consequential, and potential. The formative repertoire constitutes discourse about formations, special characteristics, or requirements for becoming a vocational agent. The performative repertoire invokes discourse that highlights actions and performances practiced in particular occupations. The consequential repertoire invokes discourse about the effects, impacts, and influence of actions in occupations. The potential repertoire invokes discourse describing possibilities, potentialities, or trends in one's career. This study draws on these four repertoires as the framework to examine how preservice teachers articulate their future career as a science teacher.

\section{Research Context}

As part of a larger study on preservice teachers' professional identities as science teachers, another researcher and I interacted with preservice teachers for six months and videotaped more than 100 hours in different settings (e.g., interviews, university courses, field work). In this study, we exemplify our argument with data from 13 preservice teachers' interviews about their career choices of becoming a science teacher. To explore the ways these preservice teachers explained their career aspirations, we examined these 13 video-recorded interviews to investigate the repertoires drawn on by preservice teachers to identify and posit themselves in the career of science teacher. To encourage students' engagement in reflecting on their career choices, we use a card-mapping activity as an interview technique to explore their justification of choosing science teacher as their future career. The participants were interviewed about their reasons for wanting to become a science teacher and the characteristics they think a successful science teacher should have. The interviews were video-recorded and transcribed, and the researchers met weekly to validate data analysis. By coding and recoding these interview transcriptions, we found reasonable and manageable chunks or patterns for analysis. These patterns of variation and consistency in a range of features allowed us to map out the patterns of interpretative repertoires that people were drawing on (Potter \& Wetherell, 1995).

\section{Interpretative Repertoires for Articulations of Becoming a Science Teacher}

Drawing on the framework of formative, performative, consequential, and potential repertoires (Hsu, Roth, Marshall, \& Guenette, 2009), the researchers examined preservice teachers' discourses about becoming a teacher. Each repertoire shows different ways of identifying the relation of self and their professional identity as a science teacher in the future. An overview of examples of these repertoires is illustrated in Table 1. 
Table 1. Examples of interpretative repertoires for articulations of becoming a science teacher

\begin{tabular}{|c|c|c|}
\hline $\begin{array}{c}\text { Interpretative } \\
\text { Repertoire }\end{array}$ & Sub-Repertoire & Examples \\
\hline Formative & N/A & $\begin{array}{l}\text { - Barbara: The first biology was a little bit difficult, everything was new, but it } \\
\text { was just fun for me and I was like hey I wanna do this, I love it, I love it. And } \\
\text { then I got into more biology classes, everything was fun, I loved all of it. } \\
\text { - Jack: As a science learner through high school, understanding the science } \\
\text { concepts made an impact on my interest in looking for answers to common } \\
\text { scientific elements. It sure was more fascinating than any other of the } \\
\text { courses. }\end{array}$ \\
\hline \multirow[b]{2}{*}{ Performative } & $\begin{array}{c}\text { Self } \\
\text { Performance }\end{array}$ & $\begin{array}{l}\text { - Jasper: I'm tutoring elementary right now. It's something I'm passionate } \\
\text { about. I figured it out. } \\
\text { - Barbara: I also started working at the YMCA, that's where I started taking } \\
\text { care of a lot of little kids. I really liked it. I like all the education. }\end{array}$ \\
\hline & $\begin{array}{c}\text { Other } \\
\text { Performance }\end{array}$ & $\begin{array}{l}\text { Gina: In middle school, my teacher, she really opened up student view of } \\
\text { science, of learning. She was a lot of fun. She was really the person that } \\
\text { opened up my eyes. I wanna be that teacher. } \\
\text { Barbara: I went back to school, and my first biology class had this amazing } \\
\text { professor, and he was amazing and I never had so much fun, and I was like, I } \\
\text { wanna be like him. }\end{array}$ \\
\hline \multirow{2}{*}{ Consequential } & $\begin{array}{l}\text { Individual } \\
\text { Impact }\end{array}$ & $\begin{array}{l}\text { Jack: And then ah what got me into, why into teach is the possibility for me } \\
\text { to be like someone, a role model, like my teachers, to me that opportunity to } \\
\text { get a teacher who can give them advice on how to follow their paths. } \\
\text { Barbara: My future goal is to become a role model for students and inspire } \\
\text { them just the way I was inspired. }\end{array}$ \\
\hline & $\begin{array}{l}\text { Collective } \\
\text { Impact }\end{array}$ & $\begin{array}{l}\text { - Wanda: Also this will help society by having more productive and educated } \\
\text { people furthering our communities. } \\
\text { David: I must also be conscious of creating a learning environment that will } \\
\text { inspire a new generation of scientists, engineers, mathematicians, and free } \\
\text { thinkers. }\end{array}$ \\
\hline Potential & N/A & $\begin{array}{l}\text { - Gina: On the internet, public places where I can gain knowledge from, } \\
\text { seminars even, sign up for a continuing education class that's gonna help me } \\
\text { to stay updated and um, just give me that extra, to keep my teaching skills up } \\
\text { to date. } \\
\text { Jacky: As teachers we need to understand that we always have room for } \\
\text { growth. One should always find ways to be a step above oneself and become } \\
\text { a better teacher than they were the year before. }\end{array}$ \\
\hline
\end{tabular}

\subsection{Formative Repertoire}

The formative repertoire invokes discourse about the preparation and formation of becoming a science teacher. Preparation may include the courses a person needs to take or the training one receives in order to fulfill the requirement of becoming a science teacher. During the trajectory of becoming a science teacher, often the life experiences in the area of science, such as science classes, field trips, hands-on activities, or particular encounters with science, play a critical role in the formation process (e.g., discourse about an interesting science topic or project that intrigued their interests and led them to pursuit a career in science teaching). Discourse about the joy, excitement, 
and benefits one receives through the preparation and formation of becoming a science teacher are the essence of formative repertoires. The following excerpts demonstrate how preservice teachers drew on formative repertoires to articulate their career choices.

In response to the interviewer's question "why did you choose to become a science teacher?" Mona described the excitement and joy she experienced when she was in an astronomy class in high school.

One of the things that I remember most was going out to the middle of the desert for an astronomy class and looking at the stars through a telescope. The assignments we did the following weeks were so fun and easy for me because I understood it. (Mona)

For Mona, the experience of the stargazing field trip was positive and enjoyable. She also enjoyed the assignments that followed afterwards. This particular field trip to the desert was a "fun" experience for Mona. Similarly, Mary described the exciting activities she experienced in her high school biology class.

I have very real memories of the days of excitement I had and couldn't wait when we had laboratory experiments. Out of my whole group I was the only one experimenting with any activity that dealt with dissecting, using microscopes, and finding new evidence of our research activities. (Mary)

Mary described the biology class in a vivid way that showed her strong affection towards science. She used words such as "could not wait" and "I was the only one experimenting" that singled out her special interest in science. That is, both Mona and Mary articulated positive emotions towards particular science-related events in the past which showed that the learning process was enjoyable.

This was especially true with Caesar, who described how his science learning journey "got cooler and cooler" from elementary school to middle school because of all the "hands-on experiments."

Science there was always experiments, we had a separate room where we would go if we had to do an experiment and they will collect black widows and have them in a case, we will go look at them in elementary school it was little stuff. But then we got to middle school and I started dissecting stuff and we started actually doing more hands-on experiments and then as you went through it just got, I mean it just got cooler and cooler to me, stuff that you can do. A very good experience. (Caesar)

Monica, Mona, and Caesar all articulated fun experiences, excitement, and fulfillment during the science learning journey. In other words, their science learning journeys were enjoyable. These science classes provided many positive experiences. In addition to the enjoyment, science learning can also be useful. For example, Jack mentioned that science helped him address his own questions about life.

I went to biology because I wanted to know more about life and how everything connects, I wanted well since I was a little kid. I had these many questions on how are we what we are now like? How does evolution made us what we are now? How animals behave? And how everything came to life aside from the point of view of my church? (Jack)

Jack mentioned that he had always been interested in life and had many questions about it. He went into biology to find answers aside from the church's point of view to his questions through science. That is, learning science was beneficial because it helped Jack address his life questions. Similarly, Monica said that science provides interesting and challenging knowledge that attracts her attention and desire to learn.

That's why I chose science, it is the hardest one and on top of that, with science, I love math, and so in science you get math $[\ldots]$ you get to learn everything from science and then what else? Chemistry, chemistry is very difficult and I love it, I love it 'cause I can't understand it yet. (Monica)

Learning science gives Monica enjoyment and fulfillment even when it is hard and challenging. Later in the interview, Monica further explained that she wants to be there for her students to solve all the questions they have.

The excerpts above show that science learning experiences can be fun and that science knowledge can be very useful and helpful. The science experience and knowledge one needs to obtain to become a science teacher are enjoyable and useful and the preservice teachers' lives. That is, one can enjoy oneself and feel fulfilled during the process of becoming a science teacher. The formative repertoires these preservice teachers used point out all kinds of positives and benefits of learning science that one can receive during the process of becoming a science teacher. 


\subsection{Performative Repertoire}

The performative repertoire involves a discourse describing actions, performances, and practices in a particular occupation or field. In this case, preservice teachers use a performative repertoire to describe actions, performances, and practices involved in their career that support their career choice (e.g., descriptions of activities performed during internships, tutoring activities, and teaching-relevant activities in the area of science education). To describe the performance repertoire in detail, it can be divided into two parts: self-performance repertoire and other-performance repertoire. The following excerpts demonstrate how preservice teachers drew on these two performative repertoires to articulate their career choices.

\subsubsection{Self-Performance Repertoire}

The self-performance repertoire refers to participants' own actions, practices, and performances relevant to their career choices (e.g., descriptions of their actions of helping people with their homework, internship practices, teaching, or volunteering work). The descriptions of one's actual practices constitute the self-performance repertoire. For example, in the following excerpt Jacky shares her story about helping her colleagues with science concepts.

To this day, it is rewarding to me that colleagues of mine will come to me for help when it comes to science. It is a rewarding experience to be able to help others and to see that they confide in me to help them understand science concepts better. (Jacky)

Jacky described events where her colleagues came to her when they need help with science. This practice requires Jacky to act like a tutor, teaching knowledge to her colleagues. Similarly, Victoria mentioned that she enjoys acting like a teacher who actually practiced designing a lesson plan in her science method course, where she learned various science-teaching methods.

I really liked that class. I wish I could have more classes like that one because it helped a lot, made me realize what I need to do in me and what's already out there. So, it was really like each group created their own lesson plan. And then we would decide on the content. And then you would provide it to the students and it was like really, really fun. (Victoria)

Victoria described her science method course as helpful and fun because it helped her to learn how to create a lesson plan and to learn about her own teaching style. Both designing and implementing a lesson plan are teaching practices teachers typically do in their daily work. These typical performances involve performative repertoires people use to justify their career choices. People may also combine both formative and performative repertoires to justify their career choices. For example, in the excerpt below, Jasper first uses formative repertoire and then draws on a performative repertoire to explain his reason for becoming a science teacher.

Basically, it started with just enjoying science. I enjoy science and I want to learn more. And then eventually came to, people would come to me, knowing that I knew certain things about science, my little sisters and cousins, and they would always asks me for help on even math, and I noticed, they would go to their teacher and they wouldn't understand things but when they came to me, I could. I wanted to teach people and I got a tutor job, and I liked it. I like teaching students. I like helping people. (Jasper)

Jasper first draws on the formative repertoire by talking about his earlier positive experiences with science that brought her joy and a desire to learn more. The benefits of science learning process during the preparation and formation of becoming a science teacher are articulated. Then, Jasper uses a self-performance repertoire that describes her tutoring practices with her sisters, cousins, and students. Jasper's actions and performances of teaching and helping people are described as a positive experience for her.

\subsubsection{Other-Performance Repertoire}

The other-performance repertoire describes the actions, performances, and practices of others in one's field. For example, a preservice teacher may mention the performance of a role model who inspired him to become a science teacher. The performances of others may come from family members, teachers, or other professionals who have motivated preservice teachers to become a science teacher through either positive or negative experiences. For example, Wanda talked about her middle school teacher who had inspired Wanda with her passion and service to others.

I decided to become a middle school teacher when I realized I want to become a good teacher as Dr. Saheba, good role model, love to serve others, and has passion for what she teaches. (Wanda) 
The outstanding performances of a role model may inspire a person, like Wanda, to become a teacher. Interestingly, the poor performances of others may also influence someone, to become a teacher. David, for example, became a teacher because of his middle school teachers' ineffective performances.

My middle school teachers were not very effective teachers, I have to say. It was this negative experience that helped me make a decision of wanting to become a middle school math/science teacher. (David)

The two excerpts above show that one's experiences with others play an important role in deciding whether to go into a particular field or not. Based on previous experiences, either positive or negative, one might consider the performances of others in judging whether one can do a good job in that field. Furthermore, the experiences can be transitional. For example, Barbara did not have a positive experience with science until she met a biology professor who demonstrated excellent teaching practices.

Thankfully, my view for science shifted in a positive direction due to an amazing biology professor, Dr. Amaya. His teachings were highly inspiring; he did not only show passion for biology but for teaching as well. (Barbara)

Barbara described how her views changed from not liking science to liking science due to Dr. Amaya's teaching. The three excerpts above show that the performances, actions, and practices of others in the field of science education play an important role in the decision to become a science teacher.

\subsection{Consequential Repertoire}

The consequential repertoire invokes discourse about the effects, impacts, and influence of actions in occupations. For the occupation of teacher, the consequential repertoire usually would emphasize the impact or difference a teacher would make on students or the society as a whole. It is a goal-oriented repertoire where participants specify their vision of being a science teacher. Consequential repertoire can also be divided into two sections: individual impact repertoire and collective impact repertoire.

\subsubsection{Individual Impact Repertoire}

The individual impact repertoire refers to the effects, impacts, and influence of a science teacher's actions directly on students. Preservice teachers may talk about their goals for the students, for example, making students be curious about science, encouraging students to stay in school, helping them do their best, etc. For example, David mentioned that he would like to help students.

Not just as a teacher, not just someone there, a person that's trying to help them, that's trying to do something great with them. (David)

David would like to go beyond for being "just" a teacher and become someone who will "do something great" with students. For Jack, he would like to become a "role model" who can give students "advice on how to follow their paths."

And then ah what got me into, why into teach is the possibility for me to, be like someone, a role model, like my teachers to me and give students that also that opportunity to get a teacher who can give them advice on how to follow their paths. (Jack)

The two excerpts above show that the impacts a teacher can make on their students are crucial for them wanting to become a teacher. These impacts may include helping students with their homework, helping students find their possible career paths, helping students discover the beauty of science, or helping students find out their talents. The individual impact repertoire demonstrates concrete goals with individual students.

\subsubsection{Collective Impact Repertoire}

The collective impact repertoire refers to the effects, impacts, and influence of the actions of a science teacher on the society. Preservice teachers talked about their goals for the nation, such as making better citizens, decreasing school dropout, helping the future of the nation, etc. For example, Jack talked about the impact of teachers on the future.

We as teachers are gonna be leading the way of the future, so how we treat our students and the knowledge we give them is gonna be impacting on how the future is gonna turn out. (Jack)

Jack said that the type of education and knowledge students receive from their teachers will "lead the way of the future." That is, teachers will make impacts on the future. Similarly, Caesar described how teachers can "shape" the leaders of tomorrow: 
Well I mean my mom and my grandma, they work in the school system, and you know so I grew up around teachers and stuff all the time and then, I also like to think that we're like shaping the leaders of tomorrow. (Caesar)

Similar to the teaching work of his mother and grandmother, Caesar thinks that teaching can make an important impact on the future because teachers are shaping the leaders of tomorrow. More specifically, Wanda aimed to address existing issues in the current education system.

An educator is, I have to take part of it, I mean, the dropout rate is pretty high, and that's gonna be the future of my nation. If I do my job well, more likely those students would be a good a productive person for the USA. They will be good citizens. (Wanda)

Since the dropout rate is high in the current education system, Wanda feels that if she does her job well as a teacher, she will be able to help students become "a productive person" and "good citizens" in the USA. The results-oriented discourse in the collective impact repertoire emphasizes the impacts a teacher can make on the society, the nation, and the future as a whole.

\subsection{Potential Repertoire}

The potential repertoire involves discourse describing possibilities, potentialities, or trends in one's career. For example, being a science teacher may be described as a career with the need for continued education and professional development. The potential repertoire depicts the future potential for self-improvement or further development in that particular career. For example, in the following excerpt, David uses the potential repertoire to describe the new things he will need to learn as an educator:

As an educator, obviously no matter what I teach it is important to be knowledgeable in my field, and as times goes on new things are gonna be thought of, new advances in technology or advances in the field itself, so I need to be open, to learn new things. (David)

David talked about the importance of knowledge for being an educator and listed things an educator would need to learn as time went by, such as new advances in technology or in the field. Similarly, Gina used the potential repertoire to identify with her career as a teacher.

The "resourceful" just you know putting myself out there. On the internet, anywhere public spaces where I can gain knowledge from seminars, sign up for a continuing education class that's gonna help me to stay updated and um, just give me that extra, to keep my teaching skills up to date. (Gina)

When asked about the key word "resourceful," Gina commented that she will use different kinds of resources to keep herself up to date through the internet, seminars, or a continuing education class. Both David and Gina articulated the importance of professional development for the teacher careers. As Jacky mentions in the following excerpt, teachers should understand that a "teacher should always find ways to be a step above oneself and become a better teacher than they were the year before."

As teachers we need to understand that we always have room for growth. One should always find ways to be a step above oneself and become a better teacher than they were the year before. (Jacky)

In Jacky's statement, she points out that there is always room for growth as a teacher. The potential repertoire singles out future possibilities, future trends, and the potential of being a science teacher.

\subsection{Frequencies of Interpretative Repertoires}

To provide an overview of these repertoires used by preservice teachers, we also conducted quantitative analysis of these interviews about becoming a science teacher. The frequencies of the four repertoires are illustrated in Table 2. Among the four repertoires, performative repertoires are the most frequently used by preservice teachers. In particular, the self-performance repertoire was used by every preservice teacher $(13,100 \%)$ when articulating their future career of being a science teacher and the other-performance repertoire was used by 11 preservice teachers $(85 \%)$. The formative repertoire was the second-most frequent repertoire, used by 11 preservice teachers $(85 \%)$. The consequential repertoire was the third-most frequent repertoire ( 8 preservice teachers [62\%] used the individual impact repertoire and 4 preservice teachers [4\%] used the collective impact repertoire). The potential repertoire was the least frequently used repertoire, used by only 3 preservice teachers $(23 \%)$. 
Table 2. Repertoires of 13 participants' discourse about becoming a science teacher

\begin{tabular}{ccccccc}
\hline \multirow{2}{*}{ Repertoires } & Formative & \multicolumn{2}{c}{ Performative } & \multicolumn{2}{c}{ Consequential } & Potential \\
\hline & & Self & Other & Individual & Collective & \\
\cline { 3 - 6 } $\begin{array}{c}\text { Number of } \\
\text { Participants }\end{array}$ & 11 & 13 & 11 & 8 & 4 & 3 \\
& $(85 \%)$ & $(100 \%)$ & $(85 \%)$ & $(62 \%)$ & $(31 \%)$ & \\
\hline
\end{tabular}

\section{Conclusions and Discussion}

The study shows that preservice teachers drew on four types of interpretative repertoires to support their career aspiration of becoming a science teacher: formative, performative, consequential, and potential. For the performative repertoire, the self-performance repertoire and other-performance repertoire were identified. Similarly, for the consequential repertoire, the individual impact repertoire and collective impact repertoire were identified. These interpretative repertoires can help us better understand the ways preservice teachers articulate their career choices and how they identify themselves in becoming a science teacher. Among these repertoires, performative repertoire was used most often by preservice teachers to explain their career pursuits of becoming a science teacher. The formative repertoire and the consequential repertoire were the second and third most frequent repertoire. The potential repertoire was the least frequently used repertoire.

The preservice teachers' uses of the four repertoires suggests that the rationale for becoming a science teacher is often attributed to one's performances, actions, and practices (e.g., tutoring practice) or is based on the observations of others' performances (e.g., previous science teachers' teaching practice). The experiencing of these performances and actions was frequently used as a repertoire to articulate participants' rationales for becoming a science teacher. Second in frequency, preservice teachers also articulated the formation process of becoming a science teacher as fun and enjoyable, mainly because of their love of and passion for science. That is, the process of becoming a science teacher is enjoyable and educational. As for the impacts, most of preservice teachers described a science teacher as someone who can make direct impacts on students and the society. A majority of the preservice teachers (62\%) pointed out the direct impacts they had on students, and some preservice teachers (31\%) mentioned the collective impacts they had on the society as a whole. A few preservice teachers (23\%) mentioned that being a science teacher has many possibilities and allows for growth and professional development.

Through the analysis of these interpretative repertoires, the study allows teachers, educators, and researchers to rethink the image of science teachers established by teachers, schools, the media, and others. For example, why is it that science teaching would be described as a career that does not require much professional development or constant learning? What are the better ways that we may use to help people understand the important impacts a science teacher can make on students and on the society as a whole?

Higher education institutions can use these findings to create new ways of educating future teacher candidates to enhance their professional identities as science teachers, such as workshops, webinars, advertisements, etc. For example, one can use the formative repertoire to describe the benefits and enjoyment involved in the process of preparing to become a science teacher, use the performative repertoire to depict the performances, actions, and practices of science teaching, use the consequential repertoire to describe the possible impacts on individuals and the society as a whole, and use the potential repertoire to articulate future possibilities and the potential for a science teacher to grow both personally and professionally. These repertoires would likely engage future teacher candidates because these repertoires are shared discursive resources among preservice teachers.

\section{Limitations and Suggestions for Further Research}

One limitation of the study is the small numbers of the participants. If researchers can interview more preservice teachers, a more diverse discourse may be revealed. Moreover, researchers may also interview inservice teachers and compared the similarities and differences between preservice and inservice teachers' discourses. This comparison may inform educators more ways to improve teacher education as a whole. As for methodology, the study also has relevance to the expansion of the theoretical frameworks science educators may use for framing and doing research. In most experimental studies, researchers presuppose language as a neutral window used to detect what an individual has in mind (Edwards \& Potter, 1992). However, Derrida (1998) asserted that "language is for the other, coming from the other, the coming of the other" (p. 68). That is, language is never neutral or owned by individuals, but rather 
is shared and mobilized in the culture. It is therefore important to have a theoretical framework that allows researchers to confront the nature of language - the foundation for almost every kind of social science research. Discursive psychology is a theory and method for studying discourse without attributing characteristics or psychological features to individuals' minds (which are forever inaccessible in any case). The discourse analyzed in this study was used by interview participants (preservice teachers) who talked about becoming science teachers. They did so by drawing on discourses and repertoires that they, by the very fact of using them, assumed to be intelligible, available, and unchallengeable. That is, rather than taking individuals as the units of analysis, which is the characteristic of most previous studies, this study analyzes and theorizes discourse of the culture as a whole. For further research, researchers may use discursive psychology as a framework to investigate diverse topics in education in general and in science education in particular.

\section{References}

Atkinson, J. M., \& Heritage, J. (Eds.) (1984). Structures of social action: Studies in conversation analysis. Cambridge, England: Cambridge University Press.

Billig, M. (1985). Prejudice, categorization and particularization: From a perceptual to a rhetorical approach. European Journal of Social Psychology, 15, 79-103. http://dx.doi.org/10.1002/ejsp.2420150107

Borman, G., \& Dowling, N. M. (2008). Teacher attrition and retention: A meta-analytic and narrative review of the research. Review of Educational Research, 78, 367-409. http://dx.doi.org/10.3102/0034654308321455

Derrida, J. (1998). Monolingualism of the other, or the prosthesis of origin. Stanford, CA: Stanford University Press.

Edwards, D., \& Potter, J. (1992). Discursive psychology. London, England: SAGE.

Garfinkel, H. (1967). Studies in ethnomethodology. Englewood Cliffs, NJ: Prentice-Hall.

Gilbert, N., \& Mulkay, M. (1984). Opening Pandora's box: A sociological analysis of scientists' discourse. Cambridge, England: Cambridge University Press.

Grissmer, D. A., Flanagan, A., Kawata, J., \& Williamson, S. (2000). Improving student achievement: What state NAEP scores tell us. Arlington, VA: RAND.

Guarino, C., Santibanez, L., \& Daley, G. (2006). Teacher recruitment and retention: A review of recent empirical literature. Review of Educational Research, 76, 173-208. http://dx.doi.org/10.3102/00346543076002173

Hsu, P.-L., Roth, W.-M., Marshall, A., \& Guenette, F. (2009). To be or not to be? Discursive resources of (dis)identifying with science related careers. Journal of Research in Science Teaching, 46, 1114-1136. http://dx.doi.org/10.1002/tea.20352

Ingersoll, R. M. (2003). Is there really a teacher shortage? Seattle, WA: Center for the Study of Teaching and Policy, University of Washington. http://dx.doi.org/10.1037/e382722004-001

Ingersoll, R. M., Merrill, L., \& May, H. (2012). Retaining teachers: How preparation matters. Educational Leadership, 69(8), 30-34.

National Academy of Science. (2007) Rising above the gathering storm: Energizing and employing America for a brighter economic future committee on prospering in the global economy of the 21 st century. Retrieved from http://www.nap.edu/catalog/11463.html

National Research Council. (1996). National science education standards. Washington, DC: National Academy Press.

Olsen, B., \& Anderson, L. (2007). Course of action: A qualitative investigation into urban teacher retention and career development. Urban Education, 42, 5-29. http://dx.doi.org/10.1177/0042085906293923

Osborne, J., \& Dillion, J. (2008). Science education in Europe: Critical reflections. A report to the Neuffield Foundation, Retrieved

from https://www.google.com/url?sa=t\&rct=j\&q=\&esrc=s\&source=web\&cd=2\&ved=0ahUKEwje562x39DMAhXF5 SYKHSdrAJUQFggjMAE\&url=http\%3A\%2F\%2Fwww.nuffieldfoundation.org\%2Fsites\%2Fdefault $\% 2 \mathrm{Ffiles} \%$ 2FSci_Ed_in_Europe_Report_Final.pdf\&usg=AFQjCNFuMddzL94ilr9XHbNqNjrNIJEe2A\&sig2=ARE81BUL 8xr5NGEavLCDkg\&bvm=bv.121421273,d.eWE

Potter, J., \& Wetherell, M. (1987). Discourse and social psychology: Beyond attitudes and behaviour. London, England: SAGE. 
Potter, J., \& Wetherell, M. (1995). Discourse analysis. In J. Smith, R. Harré, \& R. van Langenhove (Eds.), Rethinking methods in psychology. London, England: SAGE. http://dx.doi.org/10.4135/9781446221792.n6

Richardson, P. W., \& Watt, H. M. G. (2006). Who chooses teaching and why? Profiling characteristics and motivations across three Australian universities. Asia-Pacific Journal of Teacher Education, 34, 27-56. http://dx.doi.org/10.1080/13598660500480290

Roth, W.-M. (2008). The nature of scientific conceptions: A discursive psychological perspective. Educational Research Review, 3, 30-50. http://dx.doi.org/10.1016/j.edurev.2007.10.002

Weiss, R. (2007). Avenues of access to future science teachers: An interview study. Dissertation, UMI Number 3273871 ProQuest Information and Learning Company, Ann Arbor, Michigan.

Wittgenstein, L. (1958). Philosophical investigation (3rd ed., G. E. M. Anscombe, Trans.). Oxford, England: Blackwell. 